\title{
AKSELERASI:
}

JURNAL PENDIDIKAN GURU MI

Volume 1, Nomor 1, Juni 2020, Hal. 31-46

\section{ANALISIS KESULITAN BELAJAR BAHASA INDONESIA DAN ALTERNATIF PEMECAHANNYA PADA SISWA KELAS II SDN BANCARAN 4}

\author{
Yunik Astutik', Agung Setyawan ${ }^{2}$ \\ ${ }^{1}$ Universitas Trunojoyo Madura, Jl. Raya Telang 2 Kamal Bangkalan, Jawa Timur Indonesia \\ e-mail:170611100047@ student.trunojoyo.ac.id \\ ${ }^{2}$ Uni Universitas Trunojoyo Madura, Jl. Raya Telang 2 Kamal Bangkalan, Jawa Timur Indonesia \\ e-mail: Agung.setyawan@trunojoyo.ac.id
}

\begin{abstract}
The purpose of this study is to describe the learning difficulties of students in Indonesian language classes II SDN 4 Bancaran, find out the factors that influence learning difficulties in Indonesian and alternative solutions. This research uses descriptive research design. The subjects in this study were all grade II students of SDN 4 Bancaran, totaling 23 people. Data analysis uses a qualitative approach, the data that has been collected is then analyzed using qualitative descriptive data analysis techniques. Data collection techniques in this study were interviews, observation and documentation. The results showed that of 23 students there were 19 students who did not complete in learning Indonesian in order to achieve KKM. difficulty students spell letters into syllables and words, and distinguish letters $b-d, p-q$. The factors that cause difficulties in learning Indonesian Language for grade II students of SDN Bancaran 4 are internal factors, namely the students themselves and external factors of the teacher, namely ineffective classroom management where the teacher uses less teaching aids / media and the methods used are less varied and not varied innovative. Based on these results it can be concluded that the second grade students of SDN Bancaran 4 still have difficulties in learning Indonesian language lessons. Alternative solutions to student learning difficulties, namely with the help of audiovisual media in the process of learning Indonesian.
\end{abstract}

Keywords:learning difficulties, indonesian subject, alternative solutions

\begin{abstract}
ABSTRAK
Tujuan penelitian ini untuk mendeksripsikan kesulitan belajar siswa pada pelajaran Bahasa Indonesia kelas II SDN 4 Bancaran, mengetahui faktor yang mempengaruhi kesulitan belajar Bahasa Indonesia dan alternative pemecahannya. Penelitian ini menggunakan rancangan penelitian deksriptif. Subjek dalam penelitian ini adalah seluruh siswa kelas II SDN 4 Bancaran yang berjumlah 23 orang. Analisis data menggunakan pendekatan kualitatif, data yang telah dikumpulkan kemudian dianalisis dengan teknik analisis data deskriptif kualitatif. Teknik pengumpulan data dalam penelitian ini adalah wawancara, observasi dan dokumentasi. Hasil penelitian menunjukkan dari 23
\end{abstract}


siswa terdapat 19 siswa yang tidak tuntas dalam pembelajaran Bahasa Indonesia guna mencapai KKM. kesulitan siswa mengeja huruf menjadi suku kata dan kata, dan membedakan huruf b-d, p-q. Faktor-faktor yang menyebabkan kesulitan belajar Bahasa Indonesia siswa kelas II SDN Bancaran 4 adalah faktor internal yaitu peserta didik itu sendiri dan faktor eksternal dari guru yaitu pengelolaan kelas yang kurang efektif dimana guru kurang menggunakan alat peraga/media dan metode yang digunakan kurang bervariatif dan tidak inovatif. Berdasarkan hasil tersebut maka dapat disimpulkan bahwa siswa kelas II SDN Bancaran 4 masih kesulitan dalam mempelajari pelajaran Bahasa Indonesia. Alternatif pemecahan kesulitan belajar siswa tersebut, yaitu dengan bantuan media audiovisual dalam proses pembelajaran Bahasa Indonesia.

Kata Kunci: kesulitan belajar, bahasa indonesia, alternatif pemecahan

\section{PENDAHULUAN}

Kegiatan pembelajaran di sekolah merupakan kegiatan utama dalam peningkatan kualitas pendidikan nasional. Melalui proses belajar mengajar diharapkan tercapai tujuan pendidikan dalam bentuk perubahan tingkah laku peserta didik. Proses belajar ini memerlukan bahasa untuk memungkinkan manusia saling berhubungan dan berkomunikasi, saling berbagi pengalaman,belajar dari yang lain, dan meningkatkan intelektualitas diri. Tujuan pembelajaran Bahasa Indonesia antara lain untuk mengembangkan pengetahuan, keterampilan bahasa, dan sikap positif terhadap bahasa Indonesia. Bahasa memiliki peran sentral dan sangat penting dalam perkembangan intelektual, sosial, dan emosional manusia (peserta didik) dan merupakan salah satu indikator keberhasilan dalam mempelajari semua bidang studi. Pembelajaran Bahasa Indonesia adalah salah satu mata pelajaran yang dirasa penting untuk ada di dalam kurikulum SD dan serta wajib dipelajari oleh semua siswa. Dengan mempelajari bahasa Indonesia sejak SD dan memahami maknanya, siswa SD dapat menggunakannya secara tepat dan kreatif untuk berbagai macam tujuan dalam kehidupan sehari-hari. Output dari pembelajaran bahasa Indonesia di SD secara umum mengacu pada kemampuan peserta didik memahami penggunaan bahasa Indonesia dari segi bentuk, makna, dan fungsi serta mengimplikasikannya secara tepat dan kreatif untuk bermacam-macam tujuan dalam kehidupan mereka.

Belajar adalah proses yang berlangsung di dalam diri seseorang ataupun peserta didik sehingga mengalami perubahan tingkah lakunya, baik dalam berfikir, bersikap, maupun berbuat sesuatu hal. Salah satu bentuk kegiatan belajar yaitu belajar bahasa. Belajar bahasa adalah proses belajar berkomunikasi, khususnya pembelajaran bahasa 
Indonesia dimana proses pembelajaran diarahkan guna memberikan pengetahuan tentang makna kebahasaan serta melatih siswa agar terampil dalam berbahasa dan berbicara, baik secara lisan maupun tulisan. Keterampilan berbahasa mencakup empat aspek yaitu keterampilan menulis, keterampilan membaca, keterampilan berbicara, dan keterampilan menyimak. Keempat keterampilan tersebut sangat berhubungan antara satu dengan yang lainnya, dalam praktik berbahasa seseorang, keempat keterampilan tersebut saling berkaitan dan pemerolehan keterampilan berbahasa tersebut melalui suatu hubungan yang teratur, dimulai dari kemampuan menyimak, kemampuan berbicara, selanjutnya kemampuan membaca dan menulis.

Kesulitan belajar dilihat dari jenis kesulitan belajar ada yang berat dan ada yang ringan. Setiap siswa mempunyai kadar kesulitan tertentu, hal ini merupakan tugas guru sebagai pendidik dan pengajar untuk mencari solusi agar kesulitan siswa dalam belajar dapat diatasi. Bila kesulitan belajar siswa dilhat dari mata pelajaran yang dipelajrinya, maka dalam mata pelajaran Bahasa Indonesia siwa mengalami kesulitan, hal ini dikarenakan mata pelajaran Bahasa Indonesia merupakan pelajaran yang dirasa sulit bagi siswa. Kesulitan belajar dilihat dari sifat kesulitan antara siswa yang satu dengan siswa yang lainnya baik dari segi faktor-faktor penyebab kesulitan siswa dalam menguasai Bahasa Indonesia antara lain Faktor internal adalah faktor yang bersumber dari dalam diri individu itu sendiri dalam mencapai tujuan belajar. Faktor internal ini sangat besar pengaruhnya tetapi tidak disadari karena dianggap suatu hal yang biasa, sebenarnya faktor ini dapat dibagi dua bagian yaitu faktor fisilogis dan faktor psikologis.

Faktor fisiologis Faktor fisiologis adalah faktor yang bersumber dari dalam individu yang erat hubungannya dengan masalah kejasmanian terutam tentang fungsi alatalat panca indera, karena panca indera inimerupakan pintu masuk perangsang dari luar kedalam individu yang dioalah oleh untuk diterima atau tidak pengaruh tersebut. Faktor psikologis Faktor-faktor psikologis yang mempengaruhi proses belajar siswa antara lain: 1) Kecerdasan (intelegensi) 2) Bakat 3) Minat 4) Motivasi 5) Cara belajar. 2. Faktor eksternal Faktor eksternal adalah faktor yang berasal dari luar diri siswa yang dapat mempengaruhi prestasi siswa. Faktor eksternal yang dapat mempnegaruhi prestasi seseorang ada tiga yaitu faktor keluarga, faktor sekolah, dan faktor masyarakat.

Pada proses pengimplikiasiannya diperoleh kebenaran bahwa sebagian besar siswa yang tidak dapat mengembangkan pemahamannya terhadap konsep-konsep pelajaran Bahasa Indonesia dikarenakan perolehan pengetahuan dan prosesnya tidak terintegrasi 
dengan baik sehingga siswa mengalami kesulitan belajar pada mata pelajaran Bahasa Indonesia. Kesulitan-kesulitan yang sering dihadapi siswa sekolah dasar dalam menghadapi pembelajaran Bahasa Indonesia, kesulitan dalam memahami teks dan juga kesulitan dalam memahami keterampilan berbahasa pada materi Bahasa Indonesia tersebut. Hal ini juga disebabkan oleh beberapa faktor, baik faktor internal maupun eksternal dari siswa.

Pembelajaran bahasa Indonesia diharapkan dapat membantu dan menjadi salah satu cara agar peserta didik mengenal dirinya, budayanya, dan budaya orang lain, mengemukakan gagasan dan perasaan, berpartisipasi dalam masyarakat yang menggunakan bahasa tersebut, dan menemukan, menggunakan maupun mengembangkan kemampuan analitis dan imaginatif yang ada dalam dirinya.Keterampilan berbicara merupakan salah satu kemampuan yang harus dimiliki oleh setiap individu dengan tidak mengabaikan kemampuan-kemampuan yang lain seperti kemampuan menyimak, membaca, menulis, kebahasan dan sastra dalam pembelajaran bahasa Indonesia, karena dengan kemampuan tersebut individu dapat berkomunikasi dengan siapapun baik dalam situasi formal maupun informal.

Pembalajaran yang dilakukan di kelas II SDN Bancaran 4 ini sudah cukup baik, namun ada kendala yang berupa masih banyak kendala yang dihadapi para siswanya, yaitu masalah kesulitan belajar dimana kurangnya pemahaman konsep belajar siswa pada mata pelajaran Bahasa Indonesia. Berdasarkan data hasil belajar siswa kelas II yang peneliti peroleh dari data Wali Kelas II, dapat diketahui bahwa ada 19 siswa $(82,60 \%)$ dari 23 siswa keseluruhan mempunyai nilai rata-rata bahasa indonesia di bawah kkm yang telah ditentukan yaitu > 70. Hal ini menunjukkan siswa tersebut mengalami kesulitan belajar pada sebagian mata pelajaran yaitu Bahasa Indonesia dimana kesulitan siswa mengeja suku kata menjadi kata, dan analisis kesulitan siswa membedakan huruf b-d, p-q. Selain itu, berdasarkan observasi awal yang telah dilakukan, selama ini pembelajaran Bahasa Indonesia di SDN Bancaran 4 kurang memanfaatkan media pembelajaran untuk menunjang pembelajaran, terutama pada konsep-konsep abstrak yang membutuhkan penjelasan yang kongkrit.

Media dan metode pembelajaran yang digunakan oleh guru juga masih kurang bervariasi, sehingga beberapa siswa mengalami kesulitan dalam memahami materi pelajaran ini. Siswa dikatakan mengalami kesulitan dalam memahami suatu materi dapat dilihat apabila siswa belum mencapai taraf kualifikasi atau kriteria yang telah 
ditentukan.Dalam kegiatan proses pembelajaran strategi mengajar guru lebih terpusat pada guru (Teacher Centered), metode yang digunakan lebih banyak ceramah, penggunaan bahasa yang tidak terlalu diperhatikan, dan kurangnya guru mengoptimalkan penggunaan media pembelajaran baik media audio, visual dan audio visual selama proses pembelajaran.Hal tersebut membuat pembelajaran Bahasa Indonesia yang berlangsung di dalam kelas mengalami penurunan terhadap hasil belajar siswa kelas II.

Berdasarkan dari uraian diatas, maka penulis melakukan penelitian untuk mengetahui kesulitan siswa dalam memahami pembelajaran Bahasa Indonesia dengan mengambil judul: "Analisis Kesulitan Belajar Bahasa Indonesia Dan Alternatif Pemecahannya Pada Siswa Kelas II SDN Bancaran 4 ”. Berdasarkan uraian di atas, maka yang menjadi tujuan dari penelitian ini adalah sebagai berikut: 1) Untuk mendeksripsikan kesulitan belajar siswa pada pelajaran Bahasa Indonesia kelas II SDNBancaran 4. 2) Untuk mendeksripsikan faktor-faktor yang menyebabkan kesulitan belajar Bahasa Indonesia di kelas II SDN Bancaran 4 dan 3) untuk mencari alternatif pemecahan masalah kesulitan belajar siswa pada mata pelajaran Bahasa Indonesia di SDN Bancaran 4. Upaya penyelesaian yang dapat dilakukan oleh guru guna mengatasi permasalahan tersebut adalah dengan merancang pembelajaran yang dapat mengaktifkan siswa sehingga dapat meningkatkan hasil belajar siswa terutama pada muatan mata pelajaran bahasa Indonesia dan mengatasi kesulitan belajar yang dialami siswa.

Pembelajaran tersebut adalah pembelajaran yang menggunakan kombinasi media pembelajaran ataupun model pembelajaran. Belum optimalnya kemampuan siswa dalam membaca ataupun berbicara perlu dicarikan pemecahan masalah sedini mungkin. Apabila hal ini dibiarkan terus menerus berlangsung dikhawatirkan akan mempengaruhi kemampuan berbahasa lainnya. selain itu, peserta didik juga akan mengalami hambatan dalam mata pelajaran bahasa Indonesia yang akan bermuara pada rendahnya nilai prestasi hasil belajar peserta didik pada mata pelajaran bahasa Indonesia bahkan pada mata pelajaran lain sehingga diperlukan media yang inovatif guna menangani permasalahan tersebut. Salah satu di antara media yang inovatif yang dapat diterapkan atau digunakan oleh guru yaitu menggunakan media audiovisual. Media audiovisual merupakan salah satu media pembelajaran yang memiliki perpaduan saling mendukung antara gambar dan suara, sehingga mampu menggugah perasaan dan pemikiran yang menonton dan dapat dipergunakan kepada peserta didik saat pembelajaran agar lebih tersampaikan dan proses pembelajaran lebih menarik. 


\section{METODE}

Metode penelitian yang digunakan pada penelitian ini adalah penelitian kualitatif yang bersifat deskriptif dimana data kualitatif yang disajikan berupa informasi berbentuk kalimat yang memberi gambaran tentang ekspresi siswa tentang pemahaman siswa (kognitif), pandangan atau sikap siswa (afektif), aktivitas siswa mengikuti pembelajaran, perhatian, kepercayaan diri dan sejenisnya yang dapat dianalisis secara kualitatif. Landasan teori digunakan oleh peneliti sebagai petunjuk dan pemandu agar fokus penelitian sesuai dan diharapkan dengan keadaan maupun fakta di lapangan. Selain itu, landasan teori juga dapat digunakan sebagai tambahan bahan atau data untuk memberikan gambaran umum tentang latar belakang maupun masalah penelitian untuk dijadikan sebagai bahan pembahasan dalam hasil penelitian. Dengan menggunakan metode kualitatif dalam penelitian ini, diharapkan dapat diperoleh data yang mendalam dan bermakna sehingga tujuan penelitian ini dapat tercapai hendaknya. Penelitian ini ditujukan untuk mendeksripsikan kesulitan belajar siswa pada pelajaran Bahasa Indonesia kelas II SDNBancaran 4, untuk mendeksripsikan faktor-faktor yang menyebabkan kesulitan belajar Bahasa Indonesia di kelas II SDN Bancaran 4 dan untuk mencari alternatif pemecahan masalah kesulitan belajar siswa pada mata pelajaran Bahasa Indonesia di SDN Bancaran 4. Dalam penelitian ini, data yang ditemukan masih bersifat sementara, tentatif, dan akan berkembang atau berganti setelah peneliti berada dilapangan.

Data penelitian ini diperoleh dengan menggunakan instrumen penelitian berupa wawancara, observasi dan dokumentasi. Penelitian ini bersifat kolaboratif, antara guru sebagai peneliti dengan teman sejawat dan kepala sekolah serta siswa kelas II SDN Bancaran 4 Bangkalan. Menurut Ekawarna (2011:7), bersifat kolaboratif artinya dalam pelaksanaan penelitian tindakan kelas selalu terjadi kerja sama atau kerja bersama antara peneliti, guru, siswa dan pihak lain demi keabsahan dan tercapainya tujuan penelitian. Penelitian dilaksanakan pada Semester I Tahun Pelajaran 20020 di bulan Februari sampai Maret. Adapun yang menjadi lokasi penelitian ini SDN Bancaran 4 Bangkalan. Pelaksanaan penelitian ini dimulai dari perancangan penelitian, pelaksanaan, analisis data dan pembuatan laporan penelitian. Subjek dalam penelitian ini adalah seluruh siswa kelas II SDN Bancaran 4 yang berjumlah 23 orang siswa. Siswa pada kelas tersebut terdiri dari 12 orang perempuan dan 11 orang laki-laki dengan rentang usia 8-9tahun. 
Teknik Pengumpulan Data yang digunakan oleh peneliti antara lain dengan teknik tes yang terdapat bentuk tes yaitu tes tertulis. Sedangkan teknik pengumpulan data dengan menggunakan teknik nontes dapat dilakukan dengan beberapa cara diantaranya adalah melalui wawancara, observasi dan dokumentasi. Teknik pemilihan sampel yang digunakan oleh peneliti adalah Non-Probability Sampling, dimana peneliti memakai teknik sampling jenuh yaitu teknik penentuan sampel yang menjadikan semua anggota populasi sebagai sampel dengan syarat populasi yang ada kurang dari 30 orang, dikarenakan di SDN Bancaran 4 terdapat 23 siswa dikelas II sehingga memenuhi kriteria yang dibutuhkan sebagai sampel penelitian.

Alat ukur dalam penelitian disebut dengan instrumen penelitian. Dalam penelitian ini peneliti menggunakan instrumen tes tertulis, instrument pedoman wawancara dengan guru dimana wawancara yang digunakan peneliti untuk menggali informasi tentang kesulitan belajar siswa pada pembelajaran Bahasa Indonesia bersifat lentur, tidak terlalu ketat, tidak dalam suasana formal sehingga pelaksanaan wawancara tidak memakan waktu lama, lembar observasi guru dan siswa dan dokumentasi terkait nilai-nilai siswa yang mendukung hasil penelitian. Observasi atau pengamatan dilakukan dalam penelitian ini bertujuan untuk mengumpulkan data dengan cara mengamati secara langsung. Observasi dapat dilakukan secara partisipasi dan non partisipasi. Penelitian ini menggunakan observasi non partisipasi. Artinya peneliti dapat secara langsung mengamati kondisi di lapangan dengan cara melihat lokasi penelitian serta mendengarkan pendapat dari informan, serta apa saja yang berkaitan dengan pelaksanaan dalam pembelajaran, dampak yang didapat oleh siswa, faktor pendukung dan penghambat jalannya pembelajaran Bahasa Indonesia.

Studi dokumentasi menurut Sugiyono (2014:329) merupakan catatan peristiwa yang sudah berlalu. Dokumen banyak disajikan dalam berbagai bentuk, salah satunya bisa berbentuk tulisan, gambar/potret, atau karya-karya monumental dari seseorang atau narasumber dalam penelitian. Dokumen yang berbentuk tulisan misalnya catatan harian, sejarah kehidupan (life histories), biografi, peraturan, dan kebijakan. Dokumen yang berbentuk gambar, misalnya foto, gambar hidup, sketsa dan lain-lain. Dokumen yang berbentuk karya, misalnya karya seni, yang dapat berupa gambar, patung, film dan lainlain. Studi dokumen adalah pelengkap dari penggunaan metode observasi dan wawancara dalam penelitian kualitatif sehingga informasi yang terkumpul melalui dokumen-dokumen tertulis sesuai dengan masalah dan fokus penelitian lalu data tersebut akan dianalisis untuk 
melengkapi data yang di dapat dari hasil observasi. Studi dokumentasi juga merupakan data pendukung lainnya agar dapat yang didapat bisa dinyatakan valid. Dalam penelitian ini data-data yang akan didokumentasikan adalah foto kegiatan penelitian berupa kegiatan guru dan siswa dalam pembelajaran di kelas dan nilai hasil belajar siswa pada mata pelajaran bahasa Indonesia.

Teknik analisis data dalam penelitian dilakukan secara deskriptif sesuai dengan data yang terkumpul dari instrumen yang digunakan. Data yang diperoleh dari observasi awal sampai akhir penelitian dianalisis, sehingga diperoleh suatu kesimpulan. Analisis data yang digunakan dalam penelitian ini yaitu analisis deskriptif kualitatif. Metode analisis deskriptif kualitatif merupakan suatu cara untuk menganalisis atau mengolah data dengan cara menyususn secara sistematis hasil penelitan dalam bentuk kalimat atau katakata, kategori-kategori mengenai suatu objek yang dikaji oleh peneliti sehingga dapat diperoleh kesimpulan umum (Agung, 2014:110). Teknik dilakukan dengan tiga tahap yaitu, analisis sebelum lapangan, analisis selama lapangan terdiri dari reduksi data, penyajian data dan vertifikasi data, serta analisis setelah pengumpulan data terakhir dengan cara data yang telah diperoleh selama masa pengumpulan data kemudian dianalisis dari awal hingga akhir untuk penyusunan laporan sehingga diperoleh kesimpulan akhir. Secara khusus, data yang terkumpul dicari rata-rata dan dianalisis secara deskriptif kualitatif.

\section{HASIL DAN PEMBAHASAN}

Penelitian ini dilaksanakan pada siswa kelas II SDN Bancaran 4 Bangkalan dengan jumlah 23 siswa yang terdiri 12 orang perempuan dan 11 orang laki-laki dengan rentan usia 8-9tahun. Penelitian awal atau kegiatan penelitian sudah dilakukan oleh peneliti dengan kurung waktu 2 minggu (3-4kali tatap muka). Pada pertemuan awal 22 Februari 2020 peneliti melakukan tahap perijinan (Disposisi surat) dan menjelaskan skema kegiatan penelitian kepada kepala sekolah dan guru kelas yang bersangkutan menjadi sampel (Kelas II), pada pertemuan ke kedua 25 Februari 2020 peneliti melakukan kegiatan wawancara dengan guru (wali kelas) yang bersangkutan untuk mengetahui kegiatan pembelajaran dikelas II yang bersangkutan dibutuhkan oleh peneliti, karakteristik siswa, permasalahan dan hal-hal lainnya. Pada pertemuan ketiga 28 Februari 2020, peneliti melakukan kegiatan observasi pengamatan secara langsung tehadap siswa kelas II dan guru selama kegiatan pembelajaran, melakukan pendekatan dan melihat secara real permasalahan yang terjadi 
tentang kesulitan belajar ataupun kesulitan pemahaman konsep siswa kelas II pada mata pelajaran bahasa Indonesia yang masih rendah sehingga berdampak terhadap hasil belajar.

Dan pada pertemua ke empat 5 Maret 2020, peneliti memberikan rangsangan dengan memberikan stimulus berupa materi pada hari itu yang disajikan dengan bantuan media audio visual lalu siswa diberikan soal tes untuk mengetahui sejauh mana kemampuan mereka memahami konsep pembelajaran bahasa Indonesia dan separah apa kesulitan belajar mereka disertakan pendampingan oleh wali kelas dan nilai-nilai hasil ulangan siswa kelas II pada mata pelajaran Bahasa Indonesia.

Terkait hasil penelitian, pada tahap wawancara peneliti menggunakan bantuan alat perekam, menyiapkan instrument pedoman wawancara (draft) terstruktur/jelas, mencatat point-point dikertas sebagai tambahan, kegiatan wawancara dilakukan pada hari selasa, pada tanggal 25 Februari 2020 dengan 10 butir pertanyaan yang ditujukan kepada guru kelas yaitu Bapak Mohammad Safiudin, S.Pd SD dengan bantuan alat rekaman (Handphone) dan instrument wawancara sehingga peneliti mendapatkan hasil wawancara. Berdasarkan hasil wawancara dengan guru, hasil belajar siswa kelas II di SDN Bancaran 4 Bangkalan masih tergolong rendah karena beberapa faktor yang mempengaruhi, salah satunya dalam mata pelajaran bahasa Indonesia dimana siswa masih mengalami kesulitan belajar diantaranya siswa kesulitan membaca, mengeja bahkan mengenal huruf. Pemahaman konsep siswa pada mata pelajaran bahasa Indonesia khususnya masih kurang sehingga berpengaruh secara signifikan pada pembendaharan kata mereka.

Bahasa Indonesia sangat penting untuk membantu mereka berkomunikasi, apabila mereka masih kesulitan membaca ataupun mengenal huruf atau mengeja itu akan berakibat pada hasil belajar mereka disemua pembelajaran tematik. Guru juga berperan penting terhadap keberhasilan hasil belajar siswa, guru harus mampu berinovasi dan memodifikasi proses pembelajaran. Baik dari segi penggunaan metode, model dan penggunaan media untuk lebih menunjang proses pembelajaran dan melakukan upaya peningkatan pemahaman konsep pada setiap mata pelajaran yang bermasalah salah satunya bahasa Indonesia yang menjadi mata pelajaran sangat penting dan menunjang siswa untuk berkomunikasi ataupun mengerjakan soal-soal yang berkaitan.

Data hasil penelitian kesulitan siswa dalam pembelajaran Bahasa Indonesia kelas II di SDN Bancaran 4 selain didapatkan dari hasil wawancara juga didapatkan dari hasil observasi kepada siswa dan guru selama proses pembelajaran berlangsung didalam kelas. 
Analisis lembar observasi dilakukan untuk mendapatkan gambaran kesulitan siswa dalam pembelajaran Bahasa Indonesia secara umum dan faktor-faktor yang mempengaruhi kesulitan belajar siswa. Selain itu dipaparkan pula upaya-upaya yang dilakukan guru dalam mengatasi kesulitan siswa dalam belajar mata pelajaran Bahasa Indonesia kelas II. Berdasarkan hasil laporan pengamatan (observasi non partisipasi) dimana peneliti dapat secara langsung mengamati kondisi di lapangan dengan cara melihat lokasi penelitian (kelas II) serta mendengarkan pendapat dari informan baik guru kelas dan guru mata pelajaran, serta apa saja yang berkaitan dengan pelaksanaan dalam pembelajaran baik kesulitan atau hal-hal yang terjadi dikelas selama kegiatan pembelajaran berlangsung , dampak yang didapat oleh siswa dengan metode/ model/ strategi/ bantuan media dari guru, faktor pendukung dan penghambat jalannya pembelajaran Bahasa Indonesia dikelas II., peneliti memiliki catatan sendiri yang berisi informasi apa saja yang didapatkan selama proses observasi, wawancara, dokumentasi dllnya.

Lembar observasi aktivitas guru saat kegiatan pembelajaran dikelas dengan 9 butir indikator, guru sudah mampu melengkapi namun minus dibagian penggunaan media yang belum mantap sehingga perlu dipertimbangkan dan diperhitungkan kembali agar tujuan pembelajaran dapat tercapai dan hasil belajar ataupun konsep pemahaman siswa meningkat, guru perlu melakukan peningkatan/ permodelan dalam pembelajaran, peneliti juga harus melakukan tindakan guna mendapatkan hasil/ peningkatan/ perubahan yang lebih baik. Pada lembar observasi kegiatan siswa dengan 3 aspek yg diamati, sebagain besar siswa belum mampu menunjukkan sikap rata-rata mendekati cukup baik saat kegiatan pembelajaran berlangsung dikelas utamanya saat pembelajaran Bahasa Indonesia.

Berdasarkan nilai hasil ujian siswa kelas II SDN Bancaran 4 yang berkaitan dengan mata pelajaran Bahasa Indonesia dilampirkan oleh guru menjadi salah satu bentuk dokumentasi valid untuk menunjang kegiatan peneliti. Berdasar keterangan guru soal-soal ujian yang diberikan kepada siswa masing tergolong soal yang mudah guna mengukur sejauh mana pemahaman siswa setelah kegiatan pembelajaran dengan memberikan tes/ulangan, hasil nilai ulangan siswa kelas II yang dilampirkan oleh guru dan peneliti merupakan 10 soal tes pilihan ganda dengan kriteria soal persebaran ranah $\mathrm{C} 1-\mathrm{C} 2$ dan juga tes lisan sebagai tes tambahan untuk mengetahui kemampuan pribadi masing-masing siswa sebagai alat ukur sejauh mana kemampuan siswa kelas II SDN Bancaran 4 dan kesulitan masing-masing karakteristik siswa dalam belajar. 
Hasil nilai ulangan siswa inilah yang menjadi salah satu bukti untuk dijadikan dokumentasi, dimana studi dokumentasi merupakan salah satu teknik pengumpulan data dengan cara melampirkan bukti serta foto, mengumpukan informasi melalui dokumendokumen tertulis yang sesuai dengan masalah dan fokus penelitian. Hasil data tersebut akan dianalisis untuk melengkapi data yang di dapat dari hasil observasi dan wawancara. Hasil dokumentasi yang dilakukan peneliti di SDN Bancaran 4 sebagai berikut pada hasil nilai ulangan mata pelajaran Bahasa Indonesia dengan sebaran persentase masing-masing siswa yakni 4 orang $(17,39 \%)$ di kategori tuntas dan 19 orang $(82,60 \%)$ di kategori tidak tuntas. Jadi kesulitan belajar siswa kelas II di SDN Bancaran 4 Bangkalan termasuk pada kategori tinggi.

Tabel 1. Hasil Nilai Ulangan

Siswa Kelas II SDN Bancaran 4 Bangkalan

\begin{tabular}{|c|c|c|c|c|c|}
\hline \multirow[t]{2}{*}{ NO. } & \multirow[t]{2}{*}{ NAMA SISWA } & \multirow[t]{2}{*}{ KKM } & \multirow[t]{2}{*}{ NILAI } & \multicolumn{2}{|c|}{ TUNTAS } \\
\hline & & & & YA & TIDAK \\
\hline 1. & Afiq Zihny Mahmudi & 65 & 40 & - & $\sqrt{ }$ \\
\hline 2. & Ainur Ridho & 65 & 80 & $\sqrt{ }$ & - \\
\hline 3. & Aisyah & 65 & 30 & - & $\sqrt{ }$ \\
\hline 4. & Aminur Rohman & 65 & 30 & - & $\sqrt{ }$ \\
\hline 5. & Annisa Putri D & 65 & 40 & - & $\sqrt{ }$ \\
\hline 6. & Cikha Ade Tri & 65 & 50 & - & $\sqrt{ }$ \\
\hline 7. & Gilang Ramadhan & 65 & 40 & - & $\sqrt{ }$ \\
\hline 8. & Injilah Maululia & 65 & 30 & - & $\sqrt{ }$ \\
\hline 9. & Luk Luul Mukarromah & 65 & 100 & $\sqrt{ }$ & - \\
\hline 10. & Luluk Fardana & 65 & 70 & $\sqrt{ }$ & - \\
\hline 11. & Mahendra Arrizal A & 65 & 80 & $\sqrt{ }$ & - \\
\hline 12. & Maulidya & 65 & 50 & - & $\sqrt{ }$ \\
\hline 13. & Moch Rafa Hisyam & 65 & 40 & - & $\sqrt{ }$ \\
\hline 14. & Moh Lutfi Ali & 65 & 60 & - & $\sqrt{ }$ \\
\hline 15. & Muh Ali Ghufron & 65 & 60 & - & $\sqrt{ }$ \\
\hline
\end{tabular}




\begin{tabular}{|l|l|c|c|c|c|}
\hline 16. & Muh Nur Iswanto & 65 & 30 & - & \multicolumn{2}{|c|}{} \\
\hline 17. & Nafisah Salsabila & 65 & 50 & - & $\sqrt{ }$ \\
\hline 18. & Nuraini Aisyah & 65 & 50 & - & $\sqrt{ }$ \\
\hline 19. & Qolbiya Arifatir R & 65 & 10 & - & $\sqrt{ }$ \\
\hline 20. & Raihan Sahlal A & 65 & 30 & - & $\sqrt{ }$ \\
\hline 21. & Rifky Riyadi P & 65 & 60 & - & $\sqrt{ }$ \\
\hline 22. & Siti Sahrani & 65 & 50 & - & 19 \\
\hline 23. & Tiara Zahrotunnisa & 65 & 60 & - & - \\
\hline & JUMLAH & 1.140 & 4 & $82,60 \%$ \\
\hline & RATA-RATA & 49,56 & - & $17,39 \%$ \\
\hline
\end{tabular}

Berdasarkan hasil penelitian baik wawancara, observasi dan dokumentasi dengan narasumber baik guru dan siswa ataupun pihak-pihak yang membanru peneliti saat melakukan penelitian dilapangan dapat diketahui bahwa kesulitan-kesulitan siswa dalam belajar yaitu ada beberapa siswa yang masih sulit untuk mengeja huruf menjadi suku kata dan mengeja suku kata menjadi kata dan masih sulit untuk membedakan huruf, pemahaman konsep siswa yang masih kurang serta belum bisa membaca dengan lancar dan benar serta juga kenakalan siswa seperti masih serig ribut di kelas, kondisi kelas ramai dan tidak kondusif tidak serius dalam belajar pada saat mengikuti proses pembelajaran, dan masih terdapat beberapa siswa yang lebih senang bermain-main dari pada memperhatikan guru ketika menjelaskan materi. Berdasarkan hasil penelitian wawancara dengan guru yang peneliti lakukan dilapangan dapat diketahui bahwa faktor-faktor kesulitan belajar membaca permulaan siswa di kelas II SDN Bancaran 4 yaitu faktor fisik, penyebab kesulitan belajar membaca siswa dapat terjadi karena gangguan yang bersifat fisik yaitu karena sakit atau karena kurang sehat, mudah lelah, mudah mengantuk sehingga membuat konsentrasi siswa cepat hilang dan pendengaran siswa yang kurang jelas sehingga membuat siswa tidak dapat belajar membaca dengan baik.

Selain itu juga faktor dari minat siswanya itu sendiri, minat dan motivasi mereka itu sediri dalam mengikuti kegiatan pembelajaran terlihat sangat rendah karena mereka 
cendrung pasif di dalam kelas dan masih ada beberapa siswa yang suka sibuk sendiri, suka mengbrol dengan teman sebangkunya, sering tidak memperhatikan gurunya pada saat gurunya menjelaskan materi di depan kelas. Diperkirakan tingkat intelegensi mereka memang rendah hal ini terlihat pada nilai ulangan mata pelajaran Bahasa Indonesia mereka yang kurang mencapai KKM, rendahnya nilai hasil belajar siswa ini didapati dari beberapa siswa yang belum mencapai KKM, adapun KKM yang ditetapkan dari sekolah untuk mata pelajaran bahasa Indonesia adalah 65. Serta faktor keluarga yang menyebabkan keberhasilan siswa dalam hal membaca permulaan, karena hubungan orang tua dan anak itu penting sekali dalam menentukan kemajuan belajar anak seperti anak belajar membaca bersama ibunya atau ayahnya di rumah, karena waktu belajar anak di sekolah itu hanya terbatas. Jadi, dalam hal ini orang tualah yang membimbing anaknya dalam pengenalan membaca permulaan sejak usia dini. Di samping itu, faktor pengelolaan kelas yang kurang efektif yang membuat kondisi kelas menjadi tidak kondusif sehingga membuat siswa yang lainnya tidak bisa konsentrasi untuk belajar membaca.

Dengan demikian dapat ditarik kesimpulan, bahwa berdasarkan hasil wawancara dengan guru (wali kelas) dan observasi yang dilakukan oleh peneliti selama di lapangan dan menurut pendapat para ahli maka peneliti dapat menarik kesimpulan bahwa terdapat beberapa siswa yang mengalami kesulitan dalam belajar terutama Bahsa Indonesia dimana mereka sulit untuk mengeja huruf menjadi suku kata dan mengeja suku kata menjadi kata dan masih sulit untuk membedakan huruf serta pembendaharaan kata yang kurang, dan factor-faktor penyebab siswa tersebut mengalami kesulitan belajar membaca permulaan bisa dilihat dari tiga faktor yaitu, pertama faktor dari peserta didik itu sendiri yaitu faktor fisik, inteligensi, minat, motivasi, yang kedua faktor dari guru yaitu pengelolaan kelas yang kurang efektif, dan yang ketiga faktor dari keluarga yaitu kurangnya dukungan kepada anak di rumah.

\section{UCAPAN TERIMA KASIH}

Ucapan terima kasih disampaikan kepada semua pihak yang telah berperan dalam menyukseskan penyusunan artikel ini, sehingga dapat terselesaikan tepat waktu dan dapat dipergunakan sebagaimana mestinya untuk khalayak umum nantinya.

\section{SIMPULAN DAN SARAN}


Berdasarkan hasil penelitian dan pembahasan di atas, dapat disimpulkan bahwa kesulitan belajar siswa kelas II di SDN Bancaran 4 Bangkalan dari hasil penelitian kesulitan belajar siswa berada pada kategori sangat rendah dan berada pada kategori tidak tuntas beberapa siswa yang masih sulit untuk mengeja huruf menjadi suku kata juga menjadi kata dan masih sulit untuk membedakan huruf, pemahaman konsep siswa yang masih kurang serta belum bisa membaca dengan lancar dan benar serta juga kenakalan siswa seperti masih serig ribut di kelas, kondisi kelas ramai dan tidak kondusif tidak serius dalam belajar pada saat mengikuti proses pembelajaran, dan masih terdapat beberapa siswa yang lebih senang bermain-main dari pada memperhatikan guru ketika menjelaskan materi., kedua faktor-faktor yang mempengaruhi siswa yaitu faktor internal yaitu peserta didik itu sendiri yaitu faktor fisik, inteligensi, minat, motivasi, yang kedua faktor eksternal dari guru yaitu pengelolaan kelas yang kurang efektif dimana guru kurang menggunakan alat peraga/media dan metode yang digunakan kurang bervariatif dan tidak inovatif.,ketiga berdasarkan hasil wawancara yang telah dilakukan peneliti upaya yang dilakukan guru untuk mengatasi kesulitan belajar siswa yaitu, guru selalu memberikan motivasi dan mengingatkan siswa agar siswa sering berlatih mengulang pembelajaran dan mebaca dirumah, menggunakan bantuan media salah satunya media audio visual dan berkreasi/berinovasi dalam proses pembelajaran baik dari segi strategi, metode, model dan media yang digunakan oleh guru dalam mengajar dikelas.

Berdasarkan hasil penelitian yang diperoleh, maka saran yang dapat disampaikan berdasarkan penelitian yang telah dilakukan adalah: bagi siswa agar pada saat pembelajaran telah menyiapkan diri baik secara mental maupun fisik sehingga pembelajaran di kelas dapat berlangsung dengan optimal, bagi guru diharapkan dapat memberikan pemahaman tentang pentingnya belajar membaca bagi siswa, karena dengan membaca siswa akan lebih banyak memiliki wawasan dan mempermudah dalam meminimalisir kesulitan belajar yang dihadapi oleh siswa, bagi sekolah hendaknya memberikan fasilitas yang lengkap seperti buku-buku pelajaran untuk menunjang proses pembelajaran, media yang dapat digunakan selama proses pembelajaran agar kelas tidak membosankan dan inovasi lainnya, serta bagi peneliti lain penelitian ini dapat menjadi gambaran umum tentang pengelolaan kesulitan belajar siswa yang lebih luas lagi.

\section{DAFTAR PUSTAKA}


Abdurrahman, M. (2009). Pendidikan Bagi Anak Berkesulitan Belajar. Jakarta: PT Rineka Cipta.

Sugiyono. 2015. Metode Penelitian Pendidikan Pendekatan Kuantitatif, Kualitatif dan $R \& D$. Bandung: Alfabeta.

Drs. H. Rahmat, P. Hd. (2010). Media Pembelajaran Suatu Pengantar. Logung Pustaka.

Winiari Ayu, Meter Gede, Negara Gusti. (2015). Analisis Kesulitan-Kesulitan Belajar Bahasa Indonesia Kelas V Dalam Implementasi Kurikulum 2013 Di Sd Pilotingse-Kabupaten Gianyar. e-Journal PGSD Universitas Pendidikan Ganesha, 3 (1), 1-11.

Oktadiana, Bella. (2019). Analisis Kesulitan Belajar Membaca Permulaan Siswa Kelas II Pada Mata Pelajaran Bahasa Indonesia Di Madrasah Ibtidaiyah Munawariyah Palembang. Pedagogik Jurnal Ilmiah PGMI, 5 (2), 143-164.

Toriah., Rati, Ni. (2018). Analisis Kesulitan Belajar Dalam Pembelajaran Membaca Cepat Siswa Kelas V Sd Gugus VI Kecamatan Abang. E-Journal PGSD Universitas Pendidikan Ganesha, 4 (1), 1-10.

Anzar, Safni. Mardhatillah. (2017). Analisis Kesulitan Belajar Siswa Pada Pembelajaran Bahasa Indonesia Di Kelas V SD Negeri 20 Meulaboh Kabupaten Aceh Barat Tahun Ajaran 2015/2016. Jurnal Bina Gogik, 4 (1), 53-64. 